\title{
Okul Müdürlerinin Yönetim Tarzları İle Müdür Öğretmen İlişkilerinde Güven
}

\author{
DOI: 10.26466/opus.767321 \\ * \\ Halil Karadaș* - Niyazi Özer ** \\ * Dr.Öğr.Üyesi, Mardin Artuklu Üniversitesi \\ E-Posta: halil.karadas@hotmail.com \\ ORCID: $\quad \underline{0000-0003-0855-3702}$ \\ ** Doç.Dr, İnönü Üniversitesi \\ E-Posta: niyazi.ozer@inonu.edu.tr \\ ORCID: $\underline{0000-0001-7745-6645}$
}

\begin{abstract}
Öz
Bu araştırmada, öğretmenlerin görüşlerine dayalı olarak okul müdürlerinin yönetim tarzları ile müdüre güven düzeylerinin belirlenmesi amaçlanmıştır. Ayrıca bu iki değişkenin bağımsız değişkenlere göre farklılaşıp farklılaşmadığına bakılmıştır. Araştırmaya Mardin ili Midyat ilçe merkezindeki okullarda görev yapan toplam 530 öğretmen katılmıştır. Araştırmada "Okul Müdürünün Yönetim Tarzı Ölçeği" ve "Müdüre Güven Ölçeği" kullanılmıştır. Yapılan analizler sonucunda öğretmenlerin okul müdürünün yönetim tarzı ve müdüre güven algı düzeylerinin görev yapılan eğitim kademesi, cinsiyet ve farklı bir okulda çalışma isteği değişkenlerine göre anlamlı şekilde farklılaştığı sonucuna ulaşılmıştır. Okul müdürünün yönetim tarzının müdüre duyulan güven düzeyini anlamlı şekilde yordayıp yordamadığın belirlemek amacıyla yapılan regresyon analizine göre, okul müdürünün yönetim tarzının müdüre duyulan güvene ilişkin toplam varyansın \%64'ünü açıkladı̆̆g belirlenmiştir. Diğger yandan algılanan yönetim tarzı ile müdüre güven arasındaki ilişkilerin belirlenmesi için yapılan analizler sonucunda, işbirlikli yönetim tarzı ile müdüre güven arasında pozitif yönde, otokratik, ilgisiz ve karşı koyucu yönetim tarzı ile müdüre güven arasında negatif yönde bir ilişki olduğu belirlenmiştir.
\end{abstract}

Anahtar Kelimeler: Okul yönetimi, yönetim tarzı, müdüre güven, öğretmenler 


\title{
The Management Styles of The School Principals And The Trust Levels of The School Principals Based on The Teachers' Opinions
}

\begin{abstract}
In this study, it was aimed to determine the management styles of school principals and their level of trust in the principal based on the opinions of the teachers. In addition, it was examined whether these two variables differ according to the independent variables. 530 teachers who were working in the schools in the Midyat district center of Mardin province participated in the research. "School Principal's Management Style Scale" and "Trust to School Principal Scale" were used in the research. As a result of the analysis, it was determined that the teachers' perception of the management style of the school principal and trust to school principal differ significantly according to the education stage, gender and the desire to work in a different school. As a result of the regression analysis conducted to determine whether the management style of the school principal significantly predicted the trust level, it was determined that the management style of the school principal explained for $64 \%$ of the total variance related to trust to principal. On the other hand, it was determined that there was a positive relationship between the cooperative management style and the trust in the manager, and a negative relationship between the autocratic, irrelevant and counterintuitive management style and the trust in the manager.
\end{abstract}

Keywords: School management, management style, trust in manager, teachers 


\section{Giriş}

Eğitim sistemimiz, merkezden okullara doğru merkeziyetçi bir yapıda örgütlenmiştir. Eğitim-öğretim faaliyetlerinin niteliğini belirleyen pek çok karar bakanlık tarafından alınmaktadır. Alınan kararların uygulandığı, bir diğer ifadeyle hayata geçirildiği yerler ise okullardır. Bu özelliği ile okullar, bir eğitim sisteminin eylemsel sınırlarını ve çevresini belirlemektedir. (Şişman ve Turan, 2004). Diğer yandan okulların etkili bir eğitim öğretime elverişli bir yapıda örgütlenmesi gerekmektedir. Ancak insan yapısı olan her sistem gibi okullar da kusurlu olabilmektedir. Buna karşın etkili bir yönetim faaliyeti ile okul sitemi içerisinde yaşanan eksiklik ve kusurlarının giderilmesi mümkün olabilmektedir (Başaran ve Çınkır, 2013, s.129). Okullarda etkili yönetim faaliyetlerinde öncelikli görev okul yönetiminindir. Çünkü eğitim örgütlerini yönetiminin gayesi örgütü önceden pllanlanmış hedeflere ulaştırmak adına mevcut bütün katkılarını bir araya getirmek, verimli bir şekilde kullanmaktır. Ayrıca amaçlara yönelik karar ve politikalar doğrultusunda okulu yaşatmaktır (Taymaz, 2003). Okul yönetiminin önemi, yönetimin görevinden doğmaktadır. Yönetim, örgütün amaçlarını gerçekleştirmek üzere madde ve insan kaynaklarının yönetilme ve değerlendirilme süreçlerinin bütünü ve örgüte hayat verme sürecidir (Bursalığlu, 2010). Okulu yönetmenin sınırlarını, genellikle, eğitim sisteminin hedefleri belirlemektedir. Eğitim yönetimi yönetim biliminin eğitim bilimine uygulanmasından meydana geliyorsa, eğitim yönetimi ise yönetimin eğitim örgütlerine uygulanmasından ortaya çıkmaktadır (Bursalığlu, 2011).

Okul, bünyesinde barındırdığı tüm kaynakları harekete geçirilebildiğinde etkili olabilmektedir. Dolayısıyla okulda karar ve koordinasyon sürecinin en tepesini okul müdürü oluşturmaktadır (Özdemir, 2014). Çünkü okulların etkililiği hakkında yapılan çalışmalarda ulaşılan neticeler, okul yöneticisinin okullardaki verimlilik ve etkililiğinin sağlanmasında birici derecede rol oynadığını ortaya koymaktadır (Balcı, 1993). Buna ek olarak okul yöneticileri, beceri, donaım ve deneyimleri ile ögüt için vizyon yaratmada, okulun geleceğini planlamada, okuldaki paydaşları olumlu yönde kanalize etmede aktif bir rol üstlenen kişidir. Ayrıva okul müdürü okuldaki değişim çabalarında lokomotif görevi görmede en önemli rolü üstlenen kişi konumundadır (Garies ve Tschannen-Moran, 2005). Diğer yandan okul müdürlerinin okuldaki 
insan ve madde kaynaklarını yönetme konusunda farklı düşünce ve yaklaşımları da olabilir. Bazı okullarda müdürler daha işbirlikçi ve demokratik bir yönetim yaklaşımı benimseyebilirken, bazı okullarda ise daha katı ve engelleyici bir bürokratik yapıyı tercih edilebilir. Bu bağlamda okullardaki etkililik, verimlilik, başarılı olma ve okul ortamındaki iç huzurun sağlanması gibi noktalarda önemli faktörlerden birinin okul müdürlerinin benimsedikleri yönetim tarzından kaynaklandığı söylenebilir.

\section{Yönetim Tarzı}

Bir yönetim tarzını incelenirken, o yönetim tarzının hangi boyutlardan yola çıklarak araştırılacağı önemlidir. Yönetim tarzının boyutları kültürel farklılık ve ülkeden ülkeye göre çeşitlilik arzetmektedir. Bir toplumda ön plana çıan bir yönetim tarzı bir başka ülkede ciddi bir öneme sahip olamayabilir. Bu nedenle bu konuda standart bir yönetim tarzı yelpazesinden sözetmek mümkün görünmemektedir (Taş, 2007, s.261). Yönetim tarzı, bir yöneticinin örgütünü etkili kılmak için ortaya koyduğu bilgi, beceri ve gösterdiği tutumun bir bileşkesidir (Başaran, 2004). Diğer yandan yöneticiler okulu hedeflerine göre yaşatırken değişik yönetim anlayışlarının etkisinde kalabilmektedirler. Yönetim tarzı, öznel davranışlar açısından, yöneticiden yöneticiye farklılık gösterebilmektedir. Yönetim tarzları konusunda yapılan araştırmalar, yönetim tarzlarının; yöneticinin özellikleri, görev yapısını kurma davranışı, görev davranışı, ilişki davranışı, çalışanın varsayılan özellikleri ve çalışma ortamı gibi özelliklere göre irdelendiğini ortaya koymuştur (Ergin, 2008).

Yöneticiler bu öğeler doğrultusunda hangi yönetim tarzını benimsiyorlarsa, olayları, insanları bu yönde değerlendirir ve davranış sergilerler. Örgütlerde çalışan insanların niteliği güçlü bir liderlikle yönlendirilmediği sürece örgüt amaçlarını gerçekleştiremeyecektir. Bu bağlamda tercih edilen yönetim tarzı, bir örgütün yetke yapısını da oluşturmaktadır. Yetke yapısı, yöneticilerin kurumun amaçları doğrultusunda çalışmaları için tasarlanır (Bayramoğlu, 2015).

Okullardaki tüm örgütsel faaliyet ve davranışların yönetilmesi noktasında farklı düşünce ve biçimde yönetim tarzları olabilmektedir. Bu yönüyle yönetim biliminde alan yazında yönetim tarzıyla ilgili birçok yaklaşımlar bulunmaktadır. Bunlardan bazıları aşağıda açıklanacaktır. 
İlk olarak ele alacağımız yaklaşım Yönetsel Izgara (Managerial Grid) Modelidir. Blake ve Mouton' un geliştirdiği bu modelde yönetsel süreçlerde bireylerin iki farklı yaklaşım içinde oldukları ifade edilmiştir. Buna göre bireyler kendi amaçları veya başkalarının amaçlarıyla ilgilenmektedirler. Bu yaklaşım "İkili İlgi Modeli" biçiminde belitrilmektedir (Erkuş ve Tabak, 2009). Blake ve Mounton Yönetim Tarzı Matriksi'nde örgüt lideri veya yöneticinin örgütsel davranış etkinliklerinde ağırlık verdikleri yönelimleri, üretime yönelik olma ve kişiler arası ilişkilere yönelik olma olarak iki gruba ayırmışlardır (Koçel, 2014, s.682). Yönetsel ızgara modeli, örgütlerin eğitimi ve gelişimi için kullanılabilen bir yaklaşımdır. Bu yönetim anlayışının iki boyut vardır. Yönetici davranışlarında insana ve üretime dönüklüğü ifade eden boyutlardır. Bunların kombinasyonlarından ise beş yönetsel davranış biçimi açıklanmaktadır. Bu modelde, yatay eksen üretime dönüklüğü; dikey eksen ise insana dönüklüğü göstermektedir. Her bir eksen en az ilgiyi gösteren birden, en çok ilgiyi gösteren dokuza kadar ölçeklenmektedir.

Yönetsel ızgara modeli, liderliği bir kültür biçimi olarak yorumlayarak, yeni bir liderlik tarzı meydana getirmektedir. Çapraz işlevli yönler, öğrenme organizasyonları ve sürekli olarak kaliteyi iyileştirmenin önem kazandığı bir yaklaşım benimsemektedir. Bu değişim biçemleriyle, liderlik kültür modeli olan bu yaklaşım, liderlik araştırmacıları ve uygulayıcıları tarafından ciddi bir şekilde okunmayı, araştırılmayı hak etmektedir (Molloy, 1998, s.26).

Literatürde yönetim tarzıyla ilgili başka yaklaşımlar da bulunmaktadır. Başaran'a (1991, s.212) göre ise yönetim biçimleri birkaç ayrı başlık altında incelenebilir. Bunlar ; yetkeci, koruyucu, destekçi ve birlikçi yönetim anlay1şidır (1991, s.212).

\section{Yetkeci Yönetim}

Yetke, kişinin birini kendisinden üstün gördüğü bir kişilerarası ilişkidir. Yetkeci kavramı, otoriteci anlamına gelmektedir. Eğitim yönetiminde, otorite kurmayı ve ataerkilliği esas almaktadır. Otoriter ya da yetkeci kişilik kavramı, demokratik olamayan davranışlar sergileyen bireylerin kişiliklerini ifade eder. Yetkeci Yönetim kavram olarak Adam Smith' in Ekonomi Kuramına dayanmaktadır (Başaran, 2004). Yetkeci Yönetim anlayışında "birey bir üretim elamanı ve ekonomik bir unsurdur. Bireyler, yaklnızca sert ve otori- 
teye dayalı yönetim altında etkili birşekilde çalışırlar. Zira insanoğlu doğuştan tembeldir; otoriter bir şekilde yönetildiğinde ancak yararlı bir örgür elamanı olabilir." Bu yüzden, astlar iyi denetimli bir kontrol mekanizması; yanlış arama politikası içinde cezalandırma, baskı ve korkutma yoluyla çalıştırırlar. Dolayısıyla birey ve örgüt sorunlarına kayıtsız kalınan bu yönetim biçiminde astlar genel olarak amirlerinden hoşnut değildirler. Yetke; bireyin başka birini, kendisinden üstün larak algıladığ limesi, otoriteci anlamına gelmektedir. Yönetim bilimi olarak da, otorite kurmayı ve ataerkilliği esas almaktadır (Ergin, 2008). Buna göre tüm yönetsel güç, yöneticide toplanmalıdır. Yönetici gücünü, yasalardan, yönetmeliklerden ve makamından alır. Yöneticinin verdiği emirler ve talimatlar tartışılmadan yapılır. Yetkeci yönetimin geçerli olduğu eğitim kurumlarında çalışanların yöneticilere hoş görünmek için yaptığı işleri gerçek değerinden fazla gösterme çabası içinde olduğu görülebilir.

\section{Koruyucu Yönetim}

Yetkeci yönetim biçiminde çalışanlara gereken önem verilmemektedir. Genel amaç, amaçların koşulsuz, eksiksiz yerine getirilmesidir. Ancak bu şekilde çalışanlardan yeterli verim alınamamaktadır. Hawthorne çalışmaları; çalışanların mekanik bir şekilde görülmede farklı olarak, psikolojik durumlarının ön plana çıkarıldığı ve motivasyonda bilinenlerin aksine psikolojik araçların kullanılmasının gerektiği anlayışını ortaya koyan araştırmalardır. Bu akım, daha tolerasnlı ve biraz daha grup yönelimli örgütlerin oluşturulmasını hefeflemekteydi. Bu şeklilde yapılandırılan örgütlerde bireylerin yöneticilerine daha üst düzeyde güven duymaları beklentiler arasında yer almıştır (Ergin, 2008, s.24).

Diğer yandan insan ilişkileri akımının etkisiyle, örgütlerde çalışanlara daha insancıl davranılması düşüncesi önem kazanmaya başladı. Çalışanlarla iyi ilişkiler kurma yoluyla örgütsel etkililiği yükseltme görüşü, koruyucu (custodial) yönetim biçimini ortaya çıarttı (Başaran, 2004). Koruyucu Yönetim, çalınanların kendilerini güvenli hissetmelerini, yaptıkları işten tatmin olmalarını sağlamayı hedefleyen yönetim biçimidir. Kurumun amaçlarının gerçekleştirilmesinden çok, çalınanların gereksinimlerinin karşılaması ön planda 
tutulur. Çünkü bireylere sağlanan yararlarla, bireyin örgüte bağlılık göstereceği ve böylece tüm enerjisini örgütün amaçlarını gerçekleştirmek için harcayacağı düşünülmektedir (Erdoğan, 2002).

Eğitim örgütlerşinde koruyucu yönetim, eğitimin kalitesini ileriye taş1mak için, paydaşların güven içinde olmalarının, işten doyum elde etmelerinin gerektiği perspektifine dayanmaktadır. Ayrıca çalışanların özlük hakları iyileştirilmeli, iş güvencesi sağlanmalıdır. Verimliliği artırmak için çalışanların ekonomik sorunları çözülmelidir. Böylece çalışanlar bütün güçlerini örgütün amaçlarının gerçeklemesi için harcayacaklardır (Başaran, 1991, s.212).

\section{Destekçi Yönetim}

Neo-klasik yaklaşımda bireyin önemsenmesi ve bireylerin sosyal farklılılarının göz öninde bulundurulması ile klasik teoriye nazaran daha özgün bir biçime ulaştı̆̆ 1 söylenebilir. Neo-klasik teori bireyin örgüt içindeki eylemlerinin yalnızca araçsal beklentilre dayalı olmadığı anlayışı doğrultusunda paydaşların örgüt içindeki psikolojik beklentilerinin de doyurulmasının geretiğini ifade etmiştir. McGregor"e un X ve $Y$ Teorisinin $Y$ kuramı varsayımlarına bakıldığında temel olarak güven faktörünün önem kazandığı görülmektedir. $Y$ kuramı varsayımları örgüt içinde paydaşlara güven duymayı kapsayan yaklaşımları temel almaktadır. Bu bağlamda destekleyici yönetim tarzı modeli, güç yerine liderliğe dayalıdır. Yöneticiler kendilerine küçük bir fırsat sunarsa işigörenler sorumluluk üstlenecek, katkı sunmayı diliyecek ve niteliklerini yükselteceklerdir (Ergin, 2008, s.28-29).

Destekleyici yönetim anlayışı, örgüt çalışanlarının örgütün amaçlarını gerçekleştirebilmeleri için desteklenmeleri gerektiğini vurgular. Destekçi yönetim anlayışına göre eğitim örgütünün paydaşları, kendilerine önem verildiğini ve önemli görüldüklerini anladıkları zaman okulun amaçlarını gerçekleştirmek adına daha fazla çaba gösterirler. Bu yönetim anlayışına göre verimliliği artırmak için kurum çalışanlarının motivasyonunun artırılması gerekmektedir. Bu da iyi ve etkili bir liderlikle sağlanır (Başaran, 1991).

Destekçi Yönetim, gücünü ve dayandığı esasları yetke ve ekonomik kaynaklardan daha çok, liderlik becerilerinden aldığı bir yönetim anlayışıdır. Ayrıca işgörenlerin gereksinim ve doyumlarının karşılandı ̆̆ı, işgörenlerin yönetim süreçlerine katılmalarının sağlandığı yönetim anlayışıdır (Fırat, 2013). 


\section{Birlikçi Yönetim}

Birlikçi yönetim, takım çalışmasına dayanmaktadır. Takım çalışmasının birgereği olarak özgür çalışma atmosferini oluşturabilmek adına takım, liderlerini kendi aralarından seçmelidir. Birlikçi yönetim anlayışının başarıya ulaşması için, paydaşların birbirlerine karşılıklı katkıda bulunmaları gerekir. Ayrıca işi yapma ve başarmanın verdiği içsel doyum da önem arzetmektedir. $\mathrm{Bu}$ yönetim alayışında işgörenlerin her birinin kendini denetleme ve yönetmede başarılı olmaları öenmlidir. Yönetim mekanizmasına işgörenleri dahil etmemnin gayesi, karmaşıklaşan yönetimsel sorunların çözümü için örgüt elemanlarının mesleki bilgilerinden ve deneyimlerinden yararlanmaktır. Bu şekilde daha etkili ve güçlü bir örgüt oluşturrmaktır. İşgörenlerin yönetim mekanizmasına ortak olmasıyla işgörenler enerjilerinin bütünü örgütün problemlerini gidermek için harcayacaklardır. Böylece yönetenle yönetilen ayrıcalığı minimize edildiği için işgörenler örgütle özdeşleşebilmekte ve sonuç larak örgüt bir bütün olarak kenetlenebilmektedir (Başaran, 1986;Akt. Bayramoğlu, 2015). Birlikçi yönetim, örgütte çalışan tüm bireylerin bir zincirin halkaları gibi birbirine bağlı olduğu ve kararların oylama ile alındığı, herkesin eşit söz hakkına sahip olduğu, fikirlerin özgürce dile getirilebildiği, ast-üst ilişkilerinin olmadığı yönetim biçimidir (Ergin 2008).

Yukarıdaki kuramsal açılamalar ısıı̆ıında alanyazında yönetim tarzıyla ilgili çeşitli yaklaşımlar bulunduğu görülmüştür. Bu çalışmada okul müdürlerinin yönetim tarzına ilişkin demokratik, işbirlikli, otoriter, ilgisiz ve karşı koyucu yönetim tarzları (Üstüner, 2016) olarak ele alınmıştır. Diğer yandan okul müdürlerinin benimsediği yönetim yaklaşımının okul müdürü ile okul çalışanları arasındaki ilişkilerin niteliğini de önemli ölçüde etkilemediği düşünülmektedir. Bu noktadan hareketle algılanan yönetim tarzının, öğretmenyönetici ilişkilerindeki güven duygusu etkileyeceği varsayımından dolayı, güven kavramının incelenmesi de yararlı olacaktır.

\section{Müdür-Öğretmen İlişkilerinde Güven}

Rekabetin belirgin bir şekilde hissedildiği günümüz dünyasında, örgütler başarılı olabilmek için çalışanlarının mutluluğunu tesis etme yoluna gitmektedirler. İşinden mutluluk duyan kişinin bu durumu, sosyal hayatını da etkilemektedir. Her alanda yaşanan değişimlerin giderek artması, işbirliğine du- 
yulan ihtiyacın yükselmesi, takım çalışmasına duyulan inanç, örgütsel güvenin önemini artırmıştır (İşcan ve Sayın, 2010). Örgütsel başarının oluşturulmasında güvenin fonksiyonu iyi bilinmektedir. Güven, yaratıcılığa, yeniliğe ve öğrenmeye yardım etmesi açısısından örgütler için son derece önemlidir. Ayrıca güvenin örgüt içi işbirliğini sağladığı, bilgi paylaşımını teşvik ettiği, insanlar arası ilişkileri geliştirdiği, açıklık ve karşılıklı kabulü arttırdığı, çatışmayı çözme ve problem çözme becerilerini arttırdığı ifade edilmektedir (Six, 2005). Okulun kendine özgü özellikleri ve temel girdisi ile çıtısının insan olduğu göz önüne alındığında, güven temelli ilişkilerin varlığı eğitim örgütleri için oldukça önemlidir. Eğitim örgütlerinin etkili ve verimli olabilmesi, eğitsel hedeflere ulaşılabilmesi, öğrencilerin etkili bir şekilde öğrenim görebilmeleri adına, tüm paydaşların işbirliği anlayışında olmaları ve uyum içerisinde kalmaları önem arzetmektedir (Özer, Demirtaş, Üstüner ve Cömert, 2006).

Güven, örgüt bağlamında insan davranışlarını etkilediğinden, örgüt içinde ve dışında cereyan eden insan ilişkilerinin merkezinde yer almaktadır (Kouzes ve Posner, 1995). Günümüz koşulları göz önüne alındığında örgütlerin başarısının büyük ölçüde sinerji yaratmalarına bağlı olduğunu söylemek mümkündür. Bu kapsamda örgütün sosyal sermayesinin temel öğesi olan güven, bireysel ilişkileri canlı tutan bileşenlerdendir. Örgüt içi güven olmadan örgütler hedeflerine ulaşamazlar. Örgüt içi güvenin neticelerinden yararlanabilmek adına bütün paydaşların uygulamaları adil bir biçimde algıladıkları bir iş ortamı oluşturmak ve paydaşların iş doyumlarını arttırmak sonn derece önemlidir. Dolayısıyla örgütlerde güvene dayalı ilişkilerin kurulması, astların birbirlerine ve üstlerine güvenmeleri; alınan kararların adil olduğunu düşünmelerine katkı sunacaktır (İscan ve Sayın, 2010). Diğer yandan güven, okuldaki paydaşlar arasında sağlıklı bir ilişkinin geliştirilmesi, öğretimin niteliğinin arttırılması, öğrenci başarısı ve okul etkililiği açısından oldukça önemlidir. Yapılan çalışmalar güvenin; okulun işleyişi, sağlıklı bir okul ikliminin oluşturulması açısından yaşamsal bir önemi olduğunu göstermektedir (Mitchell ve Forsyth, 2004). Tschannen-Moran ve Hoy (1998) müdür ve öğretmenler arasında güvensizliğin yaşandığı bir okul ortamında ise, bireyler arası iletişimin azaldığını belirtmektedir. Ayrıca böyle bir okul ortamında öğretmenlerin kiminle neyi konuştukları konusunda, daha dikkatli olduklarını ortaya koyulmuştur. Benzer biçimde, çatışmadan sakınma, rekabet ortamı ve öğretmenlerin öz-yeterlik düzeylerinin düşük olması gibi okulda 
işbirliğini önleyen engellerin ortadan kaldırılması açısından güven önem taşımaktadır (Leonard, 1999). Öyleyse okul müdürlerinin astlarıyla iyi düzeyde iletişim kurulabildiği bir örgüt oluşturmak için, çalışanların güvenini kazanmaları gerekmektedir.

\section{Araştırmanın Amacı}

Yukarıda açıklanan kuramsal çerçeve bağlamında bu araştırmanın amacı; öğretmenlerin görüşlerine göre, okul müdürlerinin yönetim tarzları ile müdüröğretmen ilişkilerinde güven arasındaki ilişkiyi incelemek ve çeşitli değişkenler bağlamında ortaya koymaktır. Bu amaç kapsamında, araştırmada aşaıda yer alan soruların yanıtı aranmıştır.

- Öğretmenlerin, okul müdürlerinin yönetim tarzları ile müdür-öğretmen ilişkilerinde güvene ilişkin algıları ne düzeydedir?

- Öğretmenlerin, okul müdürlerinin yönetim tarzları ile müdür-öğretmen ilişkilerinde güvene ilişkin görüşleri bağımsız değişkenlere göre anlamlı farklllık göstermekte midir?

- Öğretmenlerin okul müdürlerinin yönetim tarzları ile müdür-öğretmen ilişkilerinde güvene ilişkin algıları arasındaki ilişki nasıldır?

\section{Yöntem}

Bu bölümde araştırmanın modeli, evreni, örneklemi ve araştırmada kullanılan veri toplama araçları ile toplanan verilerin analizi ile ilgili bilgiler yer almaktadır.

\section{Araştırmanın Modeli}

Araştırma, nicel araştırma modellerinde genel tarama yöntemi kullanılarak yapılmıştır. Nicel araştırmalarda bulgular kolaylıkla sayısallaştırılıp, çeşitli istatistiksel tekniklerle sunulur (Tanriöğen, 2011). Bu araştırmada nicel veriler ile öğretmenlerin okul müdürlerinin yönetim tarzları ve yönetim tarzına bağlı olarak, öğretmenlerin müdürlere duydukları güvene ilişkin algı düzeylerine, okul müdürlerinin yönetim tarzları ve yönetim tarzına bağlı olarak, öğretmenlerin müdürlere duydukları güven algı düzeylerinin kişisel özelliklerine göre anlamlı düzeyde farklılık gösterip göstermediğine ve son olarak okul müdürlerinin yönetim tarzları ve öğretmenlerin müdürlere duydukları güven arasındaki ilişki düzeyine bakılmıştır. 


\section{Evren ve Örneklem}

Araştırmanın evrenini Mardin ili Midyat ilçe merkezindeki devlet okullarında görev yapan öğretmenler oluşturmaktadır. Midyat ilçe Milli Eğitim Müdürlügü bünyesindeki merkez okullarda görev yapan öğretmenlerin en az \%50'sine ölçekler uygulanmaya çalışılmıştır. Böylece araştırmada toplamda 604 öğretmene ölçek formları dağıtılmıştır. Ancak, geri dönen ölçeklerden 74 tanesi yanlış veya eksik doldurulduğu için değerlendirmeye alınmamıştır. Böylece araştırmada toplam 530 katılımcıdan toplanan veriler değerlendirmeye alınmıştır.

\section{Veri Toplama Araçlan}

Bu çalışmada veri toplama amacıyla Okul Müdürleri Yönetim Tarzı Ölçeği (Üstüner, 2016) ve Çok Amaçlı Güven Ölçeği (Özer, Demirtaş, Üstüner ve Cömert, 2006) kullanılmıştır. Ölçeklere ilişkin bilgiler aşağıda verilmiştir.

Algılanan Müdür Yönetim Tarzı Ölçeği: Üstüner (2016) tarafından geliştirilmiş olan AMYTÖ 25 madde ve dört boyuttan meydana gelmöektedir. Ölçeğin birinci boyutu işbirlikli yönetim tarzı 7 maddeden meydana gelmektedir. Ölçeğin ikinci boyutu olan otoriter yönetim tarzı 7 maddeden, üçüncü boyutu olan ilgisiz yönetim tarzı 7 maddeden ve dördüncü boyutu lan karşı koyucu yönetim tarzı ise 4 maddeden maddelerden oluşmaktadır. Öçeğin iç tutarlılık katsayıları, işbirlikli yönetim tarzı boyutu için ".929", otoriter yönetim tarzı için ".895", ilgisiz yönetim tarzı boyutu için ".864" ve karşı koyucu yönetim tarzı boyutu için “.850" şeklinde bulunmuştur (Üstüner, 2016). Bu çalışmada yapılan hesaplamalar neticesinde ise iç tutarlılık katsayıları işbirlikli yönetim tarzı boyutunda için ".927" olarak bulunmuştur. Diğer yandan otoriter yönetim tarzı için bu değer ".858" olarak elde edilirken, ilgisiz yönetim tarzı boyutunda için ".768" ve karşı koyucu yönetim tarzı boyutunda ". 805 " şeklinde bulunmuştur.

Ölçekte yer alan boyutlardan işbirlikli yönetim tarzına ilişkin maddeler şöyledir:

"Müdürümüz okul yönetiminde öğretmenlerle birlikte hareket etmeye çalısır, Müdürümüz, sorunlar karşısında çözümü̈öğretmenlerle birlikte üretmeye çalı̧ır, Müdürümüz, bizlere rehberlik ederken güvenilir bir ilişki kurar, Müdürümüz, yeri geldiğinde öğretmenleri takdir eder, Müdürümüz, başarlarm sadece birkaç 
öğretmenin değil bütün öğretmenlerin olduğuna inanır, Müdürümüz, herhangi bir konu hakkında karar verirken bizlerin görüşlerini dikkate alı, Müdürümüz, problemler karşısında kendi çözüm yollarımızı bulmamıza yardımcı olur."

Ölçekte yer alan boyutlardan otoriter yönetim tarzına ilişkin maddeler şöyledir:

"Müdürümüz, öğretmenlerle ilişkilerinde, hatalara hoşgörü göstermeyeceğini hissettirir, Müdürümüz, öğretmenlerle iletişimlerinde ast-üst ilişkisine önem verir, Müdürümüz, öğretmenlerle ilişkilerinde başat olamaya(baskm) çalışır, Müdürümüz öğretmenlerle ilişkilerinde katıdır, Müdürümüz, bulunduğu konumdan dolayı öğretmenlerin kendisine itaat etmesini bekler, Müdürümüz, istemlerinde emir verici bir tarz kullanır, Müdürümüz, karşıllkl konuşmalarda yüksek sesle konuşur."

Ölçekte yer alan boyutlardan ilgisiz yönetim tarzına ilişkin maddeler şöyledir:

"Müdürümüz, sorunlar çözmeyi erteler, Müdürümüz, sorunlar görmezden gelir, Müdürümüz, eğitim öğretime ilişkin karşılaşılan sorunlar hakkında kendi görüş ve düşüncelerini belirtmez, Müdürümüz, her öğretmene şirin gözükmeye çalışı, Müdürümüz, okulun başarı düzeyinin ne olduğunu merak etmez, Müdürümüz, okulun eksiklerinin farkında değildir, Müdürümüz, çalışan- çalışmayan ayrımı yapmaz."

Ölçekte yer alan boyutlardan karşı koyucu yönetim tarzına ilişkin maddeler şöyledir:

"Müdürümüz, yeni bir faaliyetin yapılmasına karşı çıkar, Müdürümüz, rutinin dışına çıkmayı istemez, Müdürümüz, sanki her girişimin sonunda sorun çıkacakmış gibi davranır, Müdürümüz, kendi kurduğu bir düzenin bozulmasından hoşlanmaz."

Çok Amaçlı Güven Ölçeği: Hoy ve Tschannen-Moran (2003) tarafından geliştirilen ve Özer ve diğerleri (2006) tarafından Türkçeye uyarlanan Çok Amaçlı Güven Ölçeği; (1) meslektaşlara güven, (2) veli ve öğrencilere güven ve (3) müdüre güven alt boyutlarından meydana gelmektedir. Okullardaki güven düzeyini ölçmeye yönetlik olarak ölçeğin meslektaşlara güven boyutunda 7 madde, veli ve öğrencilere güven boyutunda 8 ve müdüre güven boyutunda 5 madde olmak üzere toplam 20 madde yer almaktadır. Ölçeğin iç tutarlılık katsayısı, meslektaşlara güven boyutu için “.93”, veli ve öğrencilere 
güven boyutu için ".94", okul müdürüne güven boyutu için “.98" ve ölçeğin geneli için ".96" olduğu, araştırmacılar tarafından daha önceden hesaplanmıştır (Özer ve diğerleri, 2006). Araştırmada ölçeğin yalnızca müdüre güven boyutu kapsamında yer alan maddelerden yararlanılmıştır. Elde edilen veriler üzerinden yapılan Cronbach Alfa iç tutarlılık katsayısı ".888" olarak hesaplanmıştır.

Çok Amaçlı Güven Ölçeğinin Müdüre güven boyutuna ilişkin maddeler şöyledir:

"Bu okuldaki öğretmenler, okul müdürüne güvenirler, Bu okuldaki öğretmenler, okul müdürünün dürüstlüğ̈̈ne inanırlar, Müdürümüz, öğretmenlerin çıarların gözetecek biçimde davranır, Bu okuldaki öğretmenler, okul müdürüne itimat edebilirler, Müdürümüz bu okulu yönetecek kabiliyetlere sahiptir."

\section{Verilerin Toplanmast}

Araştırmanın verileri, Mardin ili Midyat ilçe merkezinde görev yapan öğretmenlerle önceden hazırlanan ölçekler ile toplanmıştır. Ölçek formları çoğaltılmış ve belirlenen bir plan çerçevesinde uygulanmıştır. Ölçekler okullarda görev yapan öğretmenlere gönüllülük esasına göre uygulanmıştır. Çalışma evrenindeki okullara toplam 604 ölçek uygulanmış ve ölçeklerden 530' u değerlendirmeye alınmıştır.

\section{Verilerin Analizi}

Araştırma bulgularının analizi ve yorumlanmasında SPSS istatistik paket programından yararlanılmıştır. Araştırmanın amaçları kapsamında, okul müdürlerinin yönetim stilleri ve öğretmenlerin müdürlere ilişkin güven alg1larını belirlemede "aritmetik ortalama $(\overline{\mathrm{X}})$ ve standart sapmalara (SS)" hesaplamaları yapılmıştır. Algılanan müdür yönetim tarzı ve müdüre ilişkin güven algılarının; görev yapılan eğitim kademesine, cinsiyete, sendikaya üyelik durumuna, farklı bir okulda çalışma isteğinin olup olmadığına göre anlamlı farklılık gösterip göstermediğini belirlemek için t-testi ve tek yönlü varyans analizi kullanılmıştır. Varyans analizi sonucunda ortaya çıkan anlamlı farkın kaynağını belirlemede ise varyansların homojen olmadığı durumlarda Dunnet-C, homojen olduğu durumlarda ise Scheffe testlerinden yararlanılmıştır. Son olarak da okul müdürlerinin yönetim tarzları ve öğret- 
menlerin müdürlere karşı duydukları güven algıları arasındaki ilişki düzeyinin belirlenmesinde çoklu doğrusal regresyon analizinden istifade edilmiştir. Yapılan analizlerde anlamlılık düzeyi $\mathrm{p}<.05$ olarak göz önünde bulundurulmuştur.

\section{Bulgular ve Yorumlar}

Bulgular ve bulgulara ait yorumlar, araştırma sorularının verilişindeki sıraya uygun olarak tablolaştırılıp ve düzenlenmiştir.

\section{Öğretmenlerin Yönetim Tarzı ve Müdürlerine Güven Düzeylerine İlişkin Be- timsel İstatistik Sonuçlar}

Araştırmanın ilk sorusu “Öğretmenlerin müdüre güven ve algıladıklar müdür yönetim tarzına ilişkin puan ortalamalar ne düzeydedir?" şeklinde ifade edilmişti. Bu soruya yanıt bulabilmek amacıyla her bir ölçek ya da alt boyut için, elde edilen veriler üzerinden betimsel istatistik hesaplamaları yapılmıştır. Öğretmenlerin müdüre güven ve yönetim tarzı ölçeklerinden almış oldukları en düşük ve en yüksek puanlar, aritmetik ortalama ve standart sapma değerleri hesaplanmış, sonuçlar aşağıdaki tabloda gösterilmiştir.

Tablo 1. Öğretmenler Tarafından Algılanan Yönetim Tarzı ve Müdüre Güvene İlişkin Betimsel Analiz Sonuçlarn

\begin{tabular}{|c|c|c|c|c|c|c|}
\hline Ölçek & Boyut & Madde Sayısı & Min. & Max. & $\overline{\mathrm{X}}$ & Ss \\
\hline \multirow{5}{*}{ ఏ } & İşbirlikli & 7 & 7 & 35 & $27.01[3.85]$ & 6.08 \\
\hline & $\mathbf{\mathrm { N }}$ Otoriter & 7 & 7 & 35 & $17.02[2.43]$ & 6.37 \\
\hline & సै $\overline{\text { Ilgisiz }}$ & 7 & 7 & 30 & $12.62[1.80]$ & 4.83 \\
\hline & Karşı Koyucu & 4 & 4 & 20 & $8.38[2.09]$ & 3.68 \\
\hline & Müdüre Güven & 5 & 5 & 25 & 19.8 [3.96] & 4.46 \\
\hline
\end{tabular}

* Parantez içerisindeki değerler 5'li likert üzerinden alınan ortalama puanları göstermektedir.

Tablo 1'deki verilere bakıldığında, öğretmenlerin işbirlikli yönetim tarzı boyutundan aldıkları en düşük puanın 7, en yüksek puanın 35 olduğu, öğretmenlerin aldıkları puanların aritmetik ortalamasının " $\bar{X}=27.01$ ” ve standart sapmasının “6.08" olduğu görülmektedir. Öğretmenlerin işbirlikli yönetim tarzı boyutundan aldıklanı puanların ortalaması 5'li likert üzerinden "3.85" olarak hesaplanmıştır. Bu bulguya göre öğretmenlerin "işbirlikli yönetim 
tarzı" algı düzeylerinin "bazen" ile "çoğunlukla" düzeyi arasında olduğu söylenebilir.

Bulgular otoriter yönetim tarzı açısından incelendiğinde, bu boyuttan alınan en düşük puanın 7, en yüksek puanın 35 olduğu, öğretmenlerin aldıkları puanların aritmetik ortalamasinın “ $\overline{\mathrm{X}}=17.02$ ” ve standart sapmasının "6.37" olduğu görülmektedir. Bu bulgulara göre öğretmenlerin otoriter yönetim tarzı alg1 düzeylerinden aldıkları puanların aritmetik ortalaması 5 'li likert üzerinden 2.43 olarak hesaplanmıştır. Bu bulguya göre öğretmenlerin otoriter yönetim tarzı algı düzeylerinin "nadiren" ile "bazen" düzeyi arasında olduğu söylenilebilir. İlgisiz yönetim tarzı boyutundan alınan puanlar incelendiğinde, öğretmenlerin aldıkları en düşük puanın 7, en yüksek puanın ise 30 olduğu görülmektedir. Öğretmenlerin aldıkları puanların aritmetik ortalamasının " $\overline{\mathrm{X}}=12.62$ " ve standart sapmasının " 4.83 " olduğu tespit edilmiştir. Öğretmenlerin bu boyuttan aldıkları puanların 5'li likert üzerinden karşıllğ̣ 1.80 olarak hesaplanmıştır. Bu bulguya göre öğretmenlerin ilgisiz yönetim tarzı algı düzeylerinin "hiçbir zaman" ile "nadiren" düzeyi arasında olduğu söylenilebilir. Karşı koyucu yönetim tarzı boyutundan alınan puanlar incelendiğinde, öğretmenlerin aldıkları en düşük puanın 4, en yüksek puanın ise 20 olduğu görülmektedir. Öğretmenlerin bu boyuttan aldıkları puanların aritmetik ortalamasinın “ $\bar{X}=8.38$ ” ve standart sapmasının “3.68” olduğu tespit edilmiştir. Öğretmenlerin bu boyuttan aldıkları puanların 5'li likert üzerinden karşılığı 2.09 olarak hesaplanmıştır. Bu bulguya göre öğretmenlerin karşı koyucu yönetim tarzı algı düzeylerinin "nadiren" ile "bazen" düzeyi arasında olduğu söylenilebilir

Müdüre güven açısından incelendiğinde, bu ölçekten alınan en düşük puanın 5, en yüksek puanın 25 olduğu görülmektedir. Ölçekten alınan puanların aritmetik ortalaması “ $\overline{\mathrm{X}}=19.8$ " ve standart sapması “ 4.46 "dur. Öğretmenlerin bu ölçekten aldıkları puanlar 5'li likert üzerinden "3.96" olarak hesaplanmıştır. Bu bulgudan hareketle araştırmaya katılan öğretmenlerin müdürlere güven düzeylerinin "bazen" ile "çoğunlukla" düzeyi arasında olduğu söylenilebilir. 


\section{Algılanan Yönetim Tarzı ve Müdüre Güvenin Eğitim kademesine Göre Analiz Sonuçlar}

Araştırmanın ikinci sorusu "Öğretmenler tarafindan algılanan yönetim tarzı ve müdüre güven görev yapılan eğitim kamesi değişkenine göre anlamlı bir farklılık göstermekte midir?" şeklinde ifade edilmişti. Araştırmanın ikinci sorusuna cevap bulmak amacıyla eldeki veriler ile varyans analizi yapılmıştır. Analiz sonuçları Tablo 2'de belirtilmiştir.

Tablo 2. Algılanan Yönetim Tarzı ve Müdüre Güvenin Görev Yapılan Eğitim Kademesi Değişkenine Göre Analiz Sonuçlarn

\begin{tabular}{|c|c|c|c|c|c|c|c|c|}
\hline \multicolumn{2}{|c|}{ Ölçek/Boyut } & Görev Yeri & $\mathbf{N}$ & $\bar{X}$ & Ss & $\mathbf{F}$ & p & $\begin{array}{l}\text { Fark } \\
\text { (Scheffe) }\end{array}$ \\
\hline \multirow{16}{*}{ 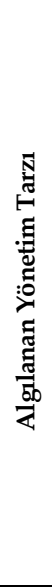 } & \multirow{4}{*}{ Işsbirlikli } & Okul Öncesi & 43 & 28.65 & 6.23 & \multirow{4}{*}{6.516} & \multirow{4}{*}{.00} & \multirow{2}{*}{$2>3$} \\
\hline & & İlkokul & 187 & 28.24 & 5.80 & & & \\
\hline & & Ortaokul & 178 & 26.12 & 6.10 & & & \multirow{2}{*}{$2>4$} \\
\hline & & Lise & 122 & 25.86 & 6.01 & & & \\
\hline & \multirow{4}{*}{ Otoriter } & Okul Öncesi & 43 & 15.30 & 6.81 & \multirow{4}{*}{9.753} & \multirow{4}{*}{.00} & $3>1$ \\
\hline & & İlkokul & 187 & 15.36 & 5.95 & & & $3>2$ \\
\hline & & Ortaokul & 178 & 18.33 & 6.35 & & & $4>1$ \\
\hline & & Lise & 122 & 18.24 & 6.20 & & & $4>2$ \\
\hline & \multirow{4}{*}{ İlgisiz } & Okul Öncesi & 43 & 12.14 & 5.04 & \multirow{4}{*}{.645} & \multirow{4}{*}{.59} & \\
\hline & & İlkokul & 187 & 12.33 & 4.68 & & & \\
\hline & & Ortaokul & 178 & 12.87 & 4.99 & & & \\
\hline & & Lise & 122 & 12.88 & 4.75 & & & \\
\hline & \multirow{4}{*}{$\begin{array}{l}\text { Karşı } \\
\text { Koyucu }\end{array}$} & Okul Öncesi & 43 & 8.06 & 3.81 & \multirow{4}{*}{6.257} & \multirow{4}{*}{.00} & \multirow{4}{*}{$3>2$} \\
\hline & & İlkokul & 187 & 7.54 & 3.44 & & & \\
\hline & & Ortaokul & 178 & 9.13 & 3.90 & & & \\
\hline & & Lise & 122 & 8.67 & 3.39 & & & \\
\hline \multirow{4}{*}{\multicolumn{2}{|c|}{ Müdüre Güven }} & Okul Öncesi & 43 & 20.74 & 4.19 & \multirow{4}{*}{4.476} & \multirow{4}{*}{.04} & \multirow{4}{*}{$2>3$} \\
\hline & & İlkokul & 187 & 20.56 & 4.29 & & & \\
\hline & & Ortaokul & 178 & 19.16 & 4.34 & & & \\
\hline & & Lise & 122 & 19.22 & 4.74 & & & \\
\hline
\end{tabular}

Tablo 2'e göre öğretmenlerin algılanan yönetim tarzı ölçeğinin işbirlikli yönetim tarzı alt boyutundan aldıkları puanlar arasında görev yapılan eğitim kademesi değişkenine göre anlamlı olarak farklılık olduğu görülmektedir. $\left[\mathrm{F}_{(3-529)}=6.516, \mathrm{p}=.00\right]$. Farkın kaynağını belirlemek üzere yapılan analizler sonucunda ilkokullarda göre yapan öğretmenlerin ortaokul ve liselerde görev yapan öğretmenlere göre, okul müdürlerini daha işbirlikli algıladıkları belirlenmiştir. Bulgular otoriter yönetim tarzı açısından incelendiğinde, öğretmenlerin puanları arasında anlamlı farklılık olduğu görülmektedir $\left[\mathrm{F}_{(3-529)}=9.753\right.$, 
$\mathrm{p}=.00]$. Çoklu karşılaştırma testleri sonucunda ortaokul ve liselerde görev yapan öğretmenlerin, okul öncesi ve ilkokullarda görev yapan öğretmenlere göre müdürlerini daha otoriter olarak algıladıkları belirlenmiştir. Katılımcıların ilgisiz yönetim tarzı boyutundan aldıkları puanlar arasında anlamlı farklılık olmadığ görülmüştür $\left[\mathrm{F}_{(3-529)}=0.645, \mathrm{p}=.59\right]$. Ancak öğretmenlerin karşı koyucu yönetim tarzı boyutundan elde ettikleri puanlar arasinda anlamlı farklılık olduğu belirlenmiştir $\left[\mathrm{F}_{(3-529)}=6.257, \mathrm{p}=.00\right]$. Analiz sonuçları ortaokullarda görevli öğretmenlerin ilkokullarda görevli öğretmenlere göre müdürlerini daha karşı koyucu olarak algıladıklarını göstermektedir.

Tablodaki bulgulara müdüre güven açısından bakıldığında öğretmenlerin güven puanları arasında anlamlı farklılık olduğu görülmektedir $\left[\mathrm{F}_{33-}\right.$ $\left.{ }_{529}=4.476, \mathrm{p}=.04\right]$. Farkın kaynağını saptamak için yapılan analizler sonucunda ilkokullarda görevli öğretmenlerin ortaokullarda görevli öğretmenle göre müdürlerine daha fazla güvendikleri belirlenmiştir.

\section{Algılanan Yönetim Tarzı ve Müdüre Güvenin Cinsiyete Göre Analiz Sonuçları}

Araştırmanın üçüncü sorusu "Öğretmenler tarafindan algılanan yönetim tarzı ve müdüre güven cinsiyet değişkenine göre anlaml bir farkllık göstermekte midir?" şeklinde ifade edilmiştir. Bu alt probleme yanıt bulmak için bağımsız gruplar için $\mathrm{t}$ testi uygulanmıştır. Analiz sonuçları aşağıdaki tabloda gösterilmiştir.

Tablo 3. Algılanan Yönetim Tarzı ve Müdüre Güvenin Cinsiyete Göre Analiz Sonuçlan

\begin{tabular}{|c|c|c|c|c|c|c|c|c|}
\hline \multicolumn{2}{|c|}{ Ölçek / Boyut } & Unvan & $\mathbf{n}$ & $\bar{X}$ & SS & sd & $t$ & $\mathrm{p}$ \\
\hline \multirow{2}{*}{$\stackrel{\vec{N}}{\vec{V}}$} & \multirow{2}{*}{ İşbirlikli } & Kadm & 243 & 27.27 & 5.94 & \multirow{2}{*}{528} & \multirow{2}{*}{.895} & \multirow{2}{*}{.37} \\
\hline & & Erkek & 287 & 22.60 & 6.20 & & & \\
\hline .5 & \multirow{2}{*}{ Otoriter } & Kadm & 243 & 16.94 & 6.46 & \multirow{2}{*}{528} & \multirow{2}{*}{-0.260} & \multirow{2}{*}{.79} \\
\hline 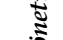 & & Erkek & 287 & 17.08 & 6.31 & & & \\
\hline 2 & \multirow{2}{*}{ İlgisiz } & Kadm & 243 & 12.25 & 4.26 & \multirow{2}{*}{528} & \multirow{2}{*}{-1.658} & \multirow{2}{*}{.09} \\
\hline \multirow{3}{*}{ 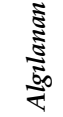 } & & Erkek & 287 & 12.98 & 5.26 & & & \\
\hline & \multirow{2}{*}{ Karşı Коуисu } & Kadm & 243 & 7.98 & 3.43 & \multirow{2}{*}{528} & \multirow{2}{*}{-2.254} & \multirow{2}{*}{$.02 *$} \\
\hline & & Erkek & 287 & 8.71 & 3.85 & & & \\
\hline \multirow{2}{*}{\multicolumn{2}{|c|}{ Müdüre Güven }} & Kadm & 243 & 19.88 & 4.08 & \multirow{2}{*}{528} & \multirow{2}{*}{0.403} & \multirow{2}{*}{.69} \\
\hline & & Erkek & 287 & 19.73 & 4.75 & & & \\
\hline
\end{tabular}

Tablo 3'deki bulgulara algılanan yönetim tarzı açısından bakıldığında, araştırmaya katılan öğretmenlerin puan ortalamaları arasında sadece karşı koyucu yönetim tarzı boyutunda anlamlı farklılık olduğu görülmektedir [t(528)= 
2.254, $\mathrm{p}=.02]$. Grupların aritmetik ortalamaları incelendiğinde erkek öğretmenlerin ( $\overline{\mathrm{X}}=8.71)$ kadın öğretmenlere $(\overline{\mathrm{X}}=7.98)$ göre okul müdürlerini daha karşı koyucu olarak algıladıkları görülmektedir. Bulgular müdüre güven aç1sindan incelendiğinde, öğretmenlerin müdüre güven ölçeğinden aldıkları puanlar arasında cinsiyet değişkenine göre anlamlı farklılık olmadığı görülmektedir $[\mathrm{t}(528)=0.403, \mathrm{p}=.69]$. Bu bulguya göre kadın ve erkek öğretmenlerin müdürlerine olan güven düzeylerinin benzer olduğu söylenebilir.

\section{Algılanan Yönetim Tarzı ve Müdüre Güvenin Sendika Üyelik Durumuna Göre Analiz Sonuçlar}

Dördüncü araştırma sorusu “Öğretmenler tarafindan algılanan yönetim tarzı ve müdüre güven sendikaya üyelik değişkenine göre anlamlı bir farkllık göstermekte midir?" şeklinde ifade edilmiştir. Bu soruya yanıt bulmak için bağımsız gruplar için $\mathrm{t}$ testi uygulanmıştır. Analiz sonuçları aşağıdaki tabloda gösterilmiştir.

Tablo 4. Algılanan Yönetim Tarzı ve Müdüre Güvenin Sendikaya Üyelik Durumuna Göre Analiz Sonuçları

\begin{tabular}{|c|c|c|c|c|c|c|c|c|}
\hline \multicolumn{2}{|c|}{ Ölçek / Boyut } & $\begin{array}{l}\text { Sendika } \\
\text { Üyeliği }\end{array}$ & $\mathbf{n}$ & $\bar{X}$ & SS & sd & $t$ & $\mathrm{p}$ \\
\hline \multirow{4}{*}{ 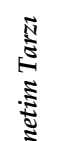 } & \multirow{2}{*}{ İşbirlikli } & Var & 384 & 26.73 & 6.17 & \multirow{2}{*}{528} & \multirow{2}{*}{-1.750} & \multirow{2}{*}{.08} \\
\hline & & Yok & 146 & 27.77 & 5.79 & & & \\
\hline & \multirow{2}{*}{ Otoriter } & Var & 384 & 17.13 & 6.50 & \multirow{2}{*}{528} & \multirow{2}{*}{.626} & \multirow{2}{*}{.53} \\
\hline & & Yok & 146 & 16.74 & 6.01 & & & \\
\hline$\stackrel{0}{2}$ & \multirow{2}{*}{ İlgisiz } & Var & 384 & 12.48 & 4.93 & \multirow{2}{*}{528} & \multirow{2}{*}{-1.103} & \multirow{2}{*}{.27} \\
\hline$\Xi$ & & Yok & 146 & 13.00 & 4.53 & & & \\
\hline$\frac{5}{5}$ & \multirow{2}{*}{ Karşı Koyucu } & Var & 384 & 8.44 & 3.77 & \multirow{2}{*}{528} & \multirow{2}{*}{.637} & \multirow{2}{*}{.52} \\
\hline & & Yok & 146 & 8.21 & 3.40 & & & \\
\hline \multirow{2}{*}{\multicolumn{2}{|c|}{ Müdüre Güven }} & Var & Var & 19.76 & 4.53 & \multirow{2}{*}{528} & \multirow{2}{*}{-.310} & \multirow{2}{*}{.76} \\
\hline & & Yok & Yok & 19.90 & 4.24 & & & \\
\hline
\end{tabular}

Tablodaki bulgular incelendiğinde, algılanan yönetim tarzı ve müdüre güven açısından araştırmaya katılan öğretmenlerin puanları arasında anlamlı farklılık olmadığı görülmektedir. Bu bulguya göre sendikaya üye olma değişkeninin algılanan yönetim tarzı ve müdüre duyulan güven üzerinde etkili olmadığı, bir diğer ifadeyle sendika üyesi olan ve olmayan öğretmenlerin alg1lanan yönetim tarzı ve müdüre güven konusunda benzer görüşlere sahip oldukları söylenebilir. 


\section{Algılanan Yönetim Tarzı ve Müdüre Güvenin Başka Bir Okulda Çalışma İsteğine Göre Analiz Sonuçlan}

Araştırmanın beşinci sorusu “Öğretmenler tarafindan alğlanan yönetim tarzı ve müdüre güven farklı bir okulda çalışma isteği değişkenine göre anlamlı bir farklllı göstermekte midir?" şeklinde ifade edilmiştir. Bu soruya yanıt bulmak için bağımsız gruplar için $\mathrm{t}$ testi uygulanmıştır. Analiz sonuçları aşağıdaki tabloda gösterilmiştir.

Tablo 5. Algılanan Yönetim Tarzı ve Müdüre Güvenin Farklı Bir Okulda Çalışma İsteği Durumuna Göre Analiz Sonuçları

\begin{tabular}{|c|c|c|c|c|c|c|c|c|}
\hline \multicolumn{2}{|c|}{ Ölçek / Boyut } & $\begin{array}{l}\text { Farklı Okulda } \\
\text { Çalışma İsteği }\end{array}$ & $\mathbf{n}$ & $\bar{X}$ & SS & sd & $\mathbf{t}$ & $\mathrm{p}$ \\
\hline \multirow{3}{*}{ 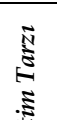 } & \multirow{2}{*}{ İşbirlikli } & Evet & 273 & 25.29 & 6.39 & \multirow{2}{*}{528} & \multirow{2}{*}{-7.054} & \multirow{2}{*}{.00} \\
\hline & & Hayer & 257 & 28.86 & 5.12 & & & \\
\hline & \multirow{2}{*}{ Otoriter } & Evet & 273 & 18.42 & 6.44 & \multirow{2}{*}{528} & \multirow{2}{*}{5.364} & \multirow{2}{*}{.00} \\
\hline$\cong$ & & Hayır & 257 & 15.53 & 5.95 & & & \\
\hline :ఫ & \multirow{2}{*}{ İlgisiz } & Evet & 273 & 13.52 & 5.15 & \multirow{2}{*}{528} & \multirow{2}{*}{4.496} & \multirow{2}{*}{.00} \\
\hline క & & Hayer & 257 & 11.67 & 4.26 & & & \\
\hline$\frac{2}{3}$ & \multirow{2}{*}{ Karşı Koyucu } & Evet & 273 & 9.27 & 3.90 & \multirow{2}{*}{528} & \multirow{2}{*}{5.926} & \multirow{2}{*}{.00} \\
\hline$z^{\infty}$ & & Hayer & 257 & 7.43 & 3.15 & & & \\
\hline \multirow{2}{*}{\multicolumn{2}{|c|}{ Müdüre Güven }} & Evet & 273 & 18.83 & 4.77 & \multirow{2}{*}{528} & \multirow{2}{*}{-5.267} & \multirow{2}{*}{.00} \\
\hline & & Hayır & 257 & 20.82 & 3.84 & & & \\
\hline
\end{tabular}

Tablodaki bulgular algılanan yönetim tarzı açısından incelendiğinde, araştırmaya katılan öğretmenlerin algılanan yönetim tarzı ölçeğinin bütün boyutlarından aldıkları puanlar arasında anlamlı farklılık olduğu görülmektedir. Grupların ortalamaları incelendiğinde farklı bir okulda çalışmak isteyen öğretmenlerin diğer öğretmenlere göre müdürlerini daha az işbirlikli, daha fazla otoriter, ilgisiz ve karşı koyucu olarak algıladıkları görülmektedir. Tablodaki bulgular müdüre güven açısından incelendiğinde, araştırmaya katılan öğretmenlerin güven ölçeğinden aldıkları puanlar arasında istatistiksel olarak anlamlı farklılık olduğu görülmektedir $[\mathrm{t}(528)=5.267, \mathrm{p}=.00]$. Grupların aritmetik ortalamaları incelendiğinde farklı bir okulda çalışmak isteyen öğretmenlerin diğer öğretmenlere göre okul müdürüne daha az güvendikleri görülmektedir. 


\section{Müdüre Duyulan Güvenin Yordanmasına İlişkin Analiz Sonuçlan}

Araştırmanın altıncı sorusu "Öğretmenlerin algıladıkları yönetim tarzı müdüre duyulan güvenin anlamlı bir yordayıcısı mıdır?" şeklinde ifade edilmiştir. Bu soruya yanıt bulmak amaciyla elde edilen veriler üzerinden çoklu regresyon analizi uygulanmıştır. Analiz sonuçları Tablo 7'de gösterilmiştir.

Tablo 7. Algılanan Yönetim Tarzının Müdüre Güveni Yordamasına İlişkin Çoklu Regresyon Analizi Sonuçları

\begin{tabular}{|c|c|c|c|c|c|c|c|}
\hline Değişken & B & $\begin{array}{l}\text { Standar } \\
\text { Hata в }\end{array}$ & $\beta$ & $\mathbf{t}$ & p & $\begin{array}{l}\text { İkili } \\
\text { r } \\
\end{array}$ & $\begin{array}{l}\text { Kismi } \\
\text { r }\end{array}$ \\
\hline Sabit & 12.142 & 1.134 & & 10.710 & .00 & & \\
\hline 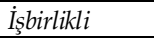 & .426 & .027 & .582 & 15.796 & .00 & .776 & .568 \\
\hline Otoriter & -.077 & .022 & -.111 & -3.450 & .00 & -.523 & -.149 \\
\hline İgisiz & -.131 & .032 & -.142 & -4.143 & .00 & -.570 & -.178 \\
\hline Karşı Кoyucu & -.105 & .047 & -.087 & -2.265 & .00 & -.613 & -.098 \\
\hline \multicolumn{8}{|c|}{$\mathrm{R}=.802, \mathrm{R}^{2}=.644, \mathrm{~F}_{(4.525)}=237.382 . \mathrm{p}=.00$} \\
\hline
\end{tabular}

Korelasyon katsayılarıba bakmak için Tablo 7'de ifade edilen verilere bakıldığında, müdüre güven ile işbirlikli yönetim tarzı arasında pozitif yönde ve yüksek düzeyde ( $\mathrm{r}=.78)$; otoriter, ilgisiz ve karşı koyucu yönetim tarzları arasında negatif yönde ve orta derecede $(\mathrm{r}$ otoriter $=-.52, \mathrm{r}$ ilgisiz $=-.57, \mathrm{r}$ karsıı koyucu $=-$ .61) bir ilişkinin var olduğu görülmektedir. Regresyon değerlerine bakıldığında bu üç değişken birlikte müdüre güven ile yüksek düzeyde ve anlamlı bir ilişki göstermektedir, $\mathrm{R}=.80, \mathrm{R}^{2}=.64, \mathrm{p}=.00$. Bu dört değişken birlikte, müdüre güvene ilişkin toplam varyansın yaklaşık olarak\% 64.4 'ünü açılamaktadır. Standardize edilmiş regresyon katsayısına ( $\beta$ ) göre, yordayıcı değişkenlerin müdüre güven üzerindeki göreli önem sırası; işbirlikli yönetim tarzı, ilgisiz yönetim tarzı, otoriter yönetim tarzı ve karşı koyucu yönetim tarzıdır. Ayrıca regresyon katsayılarının anlamlılığına ilişkin t-testi sonuçları incelendiğinde, algilanan yönetim tarzlarının hepsinin müdüre duyulan güvenin anlamlı yordayıcısı olduğu görülmektedir.

\section{Tartışma, Sonuçlar ve Öneriler}

$\mathrm{Bu}$ araştırmada algılanan yönetim tarzı ve öğretmenlerin müdüre duydukları güven düzeylerinin belirlenmesi, algılanan yönetim tarzı ve güvenin bağımsız değişkenlere göre farklılık gösterip göstermediğinin incelenmesi ve bu iki değişken arasındaki ilişkilerin belirlenmesi amaçlanmıştı. 
Görev yapılan eğitim kademesi değişkeni açısından yapılan analizler sonucunda, okul öncesi ve ilkokul kademesinde çalışan öğretmenlerin ortaokul ve lise kademesinde çalışan öğretmenlere göre okul müdürlerini daha işbirlikli algıladıkları, eğitim kademesi arttıkça öğretmenlerin müdürleri daha otoriter, karşı koyucu ve ilgisiz olarak algıladıkları belirlenmiştir. Genel bir değerlendirmeyle görev yapılan eğitim kademesi arttıkça öğretmenlerin müdürleri daha otoriter olarak algıladıkları belirlenmiştir. Bu bulgu Marks (2000) tarafından yapılan bir araştırmada sonuçlarıyla örtüşmektedir. Argon ve Dilekçi (2014) tarafından yürütülen çalışmada da branş öğretmenleri ile karşılaştırıldığında sınıf öğretmenlerinin okul müdürlerini daha demokratik, katılımcı ve paylaşımcı olarak algıladıklarını belirlemiştir. Araştırmada müdüre güven açısından elde edilen sonuçlar ise benzer biçimde okul öncesi ve ilkokul kademesindeki öğretmenlerin müdürlerine daha fazla güvendiklerini ortaya koymuştur. Ancak Özer ve arkadaşları (2006) tarafından yapılan çalışmada öğretmenlerin örgütsel güven algılarının okul türü değişkenine göre anlamlı biçimde farklılaşmadığı belirtilmiştir. Okul türü açısından elde edilen bu bulgudan hareketle özellikle ortaokul ve lise kademesinde görev yapan öğretmenlerin, okul müdürlerini daha iyi anlamalarını sağlamak amacıyla, yılın belli zamanlarında okul yönetimi konularında müdüre yardımcı olmaları ve bu şekilde okul yöneticilerine empati duymaları sağlanabilir. Bu şekilde sağlanan yetki ve rol paylaşımı, müdür-öğretmen ilişkilerini iyileştirebilir.

Cinsiyet değişkeni açısından yapılan analizler sonucunda algılanan yönetim tarzının sadece karşı koyucu yönetim tarzı boyutunda anlamlı farklılık olduğu, erkek öğretmenlerin, kadın öğretmenlere göre okul müdürlerini daha fazla karşı koyucu gördükleri belirlenmiştir. Literatürde benzer sonuçlar görmek mümkündür. Örneğin Argon ve Dilekçi (2014) yaptıkları çalışmada cinsiyetin öğretmenlerin okul müdürlerinin yönetim tarzlarına ilişkin görüşlerinin alt boyutlar olan demokratik, katılımcı-demokratik, paylaşımc1otoriter ve otoriter yönetim tarzlarında ve toplamda anlamlı farklılaşma olmadığı sonucu bulmuşlardır. Benzer biçimde Karadaş (2013) ve Ergin (2008) tarafından yapılan çalışmalarda kadın ve erkek öğretmenlerin otoriter ve pozitif yönetim tarzlarına ilişkin algıları arasında anlamlı farklılık olmadığı belirlenmiştir. Müdüre güven ölçeği için yapılan analizler sonucunda kadın ve erkek öğretmenlerin algıları arasında anlamlı farklılık olmadığı görülmüşsür. Ancak literatürde farklı sonuçlar görmek mümkündür. Özer ve arkadaşları 
(2006) tarafından yapılan çalışmada erkek öğretmenler kadın öğretmenlere oranla okullarındaki müdürleri daha güvenilir bulduklarını belirtmişlerdir.

Sendikaya üyelik değişkeni açısından yapılan analizler sonucunda hem algılanan yönetim tarzı hem de müdüre güven açısından anlamlı farklılık olmadığı belirlenmiştir. Izgar, Ertekin ve Deniz (2009) yaptıkları araştırmada sendikaların amaçları ve çalışanlara sağladığı yararlar incelendiğinde, sendikalı olmanın çalışanların ruh sağlığı üzerinde olduğu kadar iş doyumları üzerinde de olumlu etkilerinin olacağını belirtmektedir. Çünkü sendikalar üyelerinin çıkarlarını korumak ve geliştirmek için çalışmalar yaparlar. Ancak bu araştırmadan elde edilen sonuçlar sendika üyesi olup olmamanın yönetim tarzı ve müdüre güven üzerinde anlamlı bir etkisinin olmadığını göstermiştir. Araştırmadan elde edilen bu bulgunun nedenlerinin ortaya konulabilmesi için nitel çalışmalar yürütülebilir.

Farklı bir okulda çalışma isteği değişkeni açısından yapılan analizler sonucunda hem yönetim tarzı ve hem de müdüre güven ölçeğinde anlamlı farklılık olduğu belirlenmiştir. Farklı bir okulda çalışmak istemeyen öğretmenler, diğer öğretmenlere göre okul müdürüne daha az güvenmekte ve müdürün daha az işbirlikçi bir yönetim tarzı sergilediğini düşünmektedir. Buna karşı okulunu değiştirmek isteyen öğretmenler müdürlerini daha otoriter, ilgisiz ve karşı koyucu algılamaktadır. Bu durumun uzun süreli ilişkilerde yaşanan olumsuzlukların etkili olduğu düşünülebilir. Bu sonuçtan hareketle öğretmenlerin aynı müdürle çalısma süreleri konusunda düzenlemeler yapılabilir. Benzer biçimde okul müdürleri için uygulanmakta olan rotasyon uygulamasına devam edilebilir veya benzer bir rotasyon uygulamasının öğretmenler için de getirilmesi düşünülebilir.

Algılanan yönetim tarzı ile müdüre güven arasındaki ilişkilerin belirlenmesi için yapılan analizler sonucunda, işbirlikli yönetim tarzı ile müdüre güven arasında pozitif yönde, otokratik, ilgisiz ve karşı koyucu yönetim tarzı ile müdüre güven arasında negatif yönde bir ilişki olduğu belirlenmiştir. Bununla birlikte analiz sonuçları algılanan yönetim tarzının müdüre güven puanlarına ilişkin varyasın yaklaşık olarak $\% 64$ 'ü gibi büyük bir oranını açıkladığını göstermiştir. Müdür ve öğretmenler arasında kurulan etkileşim öğretmenlerde müdürün yönetim tarzına ilişkin olumlu bir etki oluşturur. Oluşan bu yönetim tarzı öğretmenlerin müdüre güven duymasını sağlar (Öztürk, 2000). Bu sonuçlardan yola çıkarak müdürün yönetim tarzındaki olumlu 
davranışların artmasıyla; öğretmenlerin müdüre duydukları güveninin arttığı ve bunun sonucu olarak, öğretmenler ile müdürler arasında daha iyi ilişkiler kurulabileceği sentezine ulaşabiliriz.

Araştırmadan elde edilen ve yukarıda ifade edilen bulgular değerlendirilirken araştırmanın sınırlılıkları göz önünde bulundurulmalıdır. Bu araştırma Mardin ili Midyat ilçesinden toplanan verilerle yapılmıştır. Araştırmanın daha büyük örneklemlerde yapılması yönetim tarzı ve güven arasındaki ilişkinin daha net bir şekilde belirlenmesine katkı sağlayabilir. Benzer bir araştırma hem öğretmen hem de okul yöneticilerinin görüşleri alınmak suretiyle, karşılaştırmalı bir şekilde yapılabilir. Ayrıca öğrenci ve öğretmenlerin katılımıyla yapılacak nitel bir araştırma, konunun daha derinlemesine incelenmesine olanak sağlayabilir. Sonuç itibariyle, okulları sorunlar yumağı olarak nitelemek mümkündür. Bu nedenle sorunsuz okul düşünülemez. Fakat bütün bu sorunlara rağmen, iyi bir okul müdürü, sorunların varllğından dolayı şikâyette bulunmak yerine var olan sorunlar için çözüm yolları üretmelidir. Okul müdürü her şeyden önce okuldaki sorunları önceden tahmin etmeli ve enerjisinin önemli bir kısmını okuldaki öğretmenler ve okul çalışanlarıyla birlikte çözülebilecek sorunlara vermelidir (Açıkalın, Şişman ve Turan, 2007). 
EXTENDED ABSTRACT

\title{
The Management Styles of The School Principals And The Trust Levels of The School Principals Based on The Teachers' Opinions
}

\author{
Halil Karadaş - Niyazi Özer \\ Mardin Artuklu University -İnönü University
}

In this study, it was aimed to determine the perceived management style and teachers' level of trust in the principal, to examine whether the perceived management style and trust differ according to the independent variables and to determine the relationships between these two variables. As a result of the analysis made within this scope, it was seen that there was a significant difference between the scores of the teachers' perceived management style sub-dimension of the cooperative management style sub-dimension according to the education level variable. As a result of the analyzes made to determine the source of the difference, it was determined that teachers who work in primary schools perceive school principals more collaboratively than teachers working in secondary and high schools. When the findings were examined in terms of authoritarian management style, it was seen that there was a significant difference between the scores of the teachers. As a result of the multiple comparison tests, it was determined that teachers working in secondary and high schools perceive their principals as more authoritative than teachers working in pre-school and primary schools. It was observed that there was no significant difference between the scores of the participants in the indifferent management style dimension. However, it was determined that there is a significant difference between the scores of the teachers in the dimension of the opposing management style. Analysis results show that teachers working in secondary schools perceive their principals as more opposing than teachers working in primary schools. When examined in terms of trust in the principal, it was seen that there was a significant difference between the trust scores of the teachers. As a result of the analysis made to determine which group or groups the difference stems from, it was determined 
that teachers working in primary schools trust their principals more than teachers working in secondary schools.

When examined in terms of research findings, it was seen that there was a significant difference only in the dimension of opposing management style among the mean scores of the teachers participating in the study. When the arithmetic averages of the groups were examined, it was seen that male teachers perceived school principals as more opposing than female teachers. When the findings were examined in terms of trust in the principal, it was observed that there was no significant difference between the scores of the teachers' trust in principals according to the gender variable. According to this finding, it can be said that the trust levels of male and female teachers in their principals are similar. It was observed that there was no significant difference between the scores of the teachers who participated in the study in terms of perceived management style and trust in the principal. According to this finding, it can be said that the variable of being a union member does not have an effect on the perceived management style and trust in the principal, in other words, teachers who are union members and who are not members have similar views on perceived management style and trust in the principal. On the other hand, it was observed that there was a significant difference between the scores of the teachers participating in the study from all dimensions of the scale. When the averages of the groups were examined, it was observed that teachers who wanted to work in a different school perceived their principals as less cooperative, more authoritarian, indifferent and opposing than other teachers. When the findings in the table were examined in terms of trust in the principal, it was seen that there was a statistically significant difference between the scores of the teachers participating in the study from the trust scale. When the arithmetic averages of the groups were examined, it was seen that teachers who wanted to work in a different school trusted the principal less than other teachers.

Regression analysis to find the relationship between the variables, when looked in terms of correlation coefficients, between trust in the manager and cooperative management style positively and at a high level $(\mathrm{r}=.78)$; It has been observed that there is a negative and moderate ( $\mathrm{r}$ authoritarian $=-.52, \mathrm{r}$ irrelevant $=-.57$, $\mathrm{r}$ opposing $=-.61$ ) relationship between authoritarian, indifferent and opposing management styles. Looking at the regression values, these three variables together show a high level and significant relationship 
with trust in the manager $(\mathrm{R}=.80, \mathrm{R} 2=.64, \mathrm{p}=.00)$. These four variables together explain approximately $64.4 \%$ of the total variance regarding trust in the principal. According to the standardized regression coefficient, the relative importance order of the predictor variables on trust in the manager; cooperative management style, apathetic management style, authoritarian management style and opposing management style. In addition, when the ttest results regarding the significance of the regression coefficients were examined, it was seen that all perceived management styles were significant predictors of trust in the manager.

\section{Kaynakça / References}

Açkalın, A. (1998). Teknik ve toplumsal yönleriyle okul yöneticiliği. Ankara: Pegem A Yayincilik.

Açıkalın, A., Şişman, M. ve Turan, S. (2003). Bir insan olarak okul müdürü, Ankara: Pegem A Yayıncllk.

Argon, T. ve Dilekçi, Ü. (2014). Öğretmenlerin okul müdürlerinin yönetim tarzları ve kurumsal itibara yönelik algıları arasındaki ilişki. International Periodical For the Languages, Literature and History of Turkish or Turkic, 9(2), 161-181.

Balcı, A. (2011). Sosyal bilimlerde araştırma. Yöntem, teknik ve ilkeler. (9. Baskı). Ankara: Pegem Akademi.

Başaran, İ. E. ve Çınkır, Ş. (2013). Türk eğitim sistemi ve okul yönetimi. (4. Baskı). Ankara: Siyasal Kitabevi.

Başaran, İ. E. (2004). Yönetimde insan ilişkileri. 3. Baskı, Ankara, Nobel Yayınları

Başaran, İ. E. (1991). Örgütsel davramış insanın üretim gü̈ü. Ankara: Gül Yayınevi.

Başaran, İ. E. (1986). Öğretmenlerin yönetime katılması. Eğitim Bilimleri Fakültesi Dergisi, 19(1).

Bayramoğlu, A. (2015). Ortaöğretim kurumlarnnda görevli öğretmenlerin okul yönetimine katıllm durumlarnnn incelenmesi. Yayımlanmamış Yüksek lisans Tezi, İstanbul Aydın Üniversitesi Sosyal Bilimleri Enstitüsü, İstanbul.

Bursalığlu, Z. (2010). Açklamalı eğitim yönetimi terimleri sözlü̈̆̈̈. (2. Baskı) Ankara: Pegem A Yayincllk.

Bursalığlu, Z. (2011). Okul yönetiminde yeni yapı ve davranıs. (16. Baskı) Ankara: Pegem A Yayincilik.

Erdoğan, İ. (2002). Okul yönetimi ve öğretim liderliği. (3. Baskı). İstanbul: Sistem Yayıncllk. Ergin, U. (2008). Yetkeci yönetim tarzmmn öğretmen performansina etkisi. Yayımlanmamış Yüksek lisans Tezi, Marmara Üniversitesi Fen Bilimleri Enstitüsü, İstanbul. 
Erkuş, A ve Tabak, A. (2009). Beş faktör kişilik özelliklerinin çalışanların çatışma yönetim tarzlarına etkisi: Savunma sanayiinde bir araştırma. Atatürk Üniversitesi İktisadi ve İdari Bilimler Dergisi, 23 (2), 214.

Feingold, A. (1994). Gender differences in personality: A meta-analysis. Psychological Bulletin, 116(3), 429.

Furat, H. (2013). Adana il merkezindeki ilkokullarda göreoli okul yöneticilerinin yönetim biçimleri. Yayınlanmamış Yüksek Lisans Tezi, Çağ Üniversitesi Sosyal Bilimler Enstitüsü, Mersin.

Forsyth, P. B., Adams, C. M. ve Hoy, W. K. (2011). Collective trust: why schools can't tmprove without it. New York: Teachers College Press.

Duran, C. O. (2011). Ortaöğretim okullarnnda okul yönetimine yansiyan disiplin sorunlan ve okul yöneticilerinin çözüm yaklaşımları. Yayımlanmamış Yüksek Lisans Tezi, Uşak Üniversitesi, Sosyal Bilimler Enstitüsü, Uşak.

Gareis, C. R. ve Tschannen-Moran, M. (2004, April). Principals' sense of efficacy and trust. Paper accepted to be presented at the annual meeting of the American Educational Research Association, San Diego.

Güçlü, H. (2006). Turizm sektöründe durumsal faktörlerin örgütsel bağhllk üzerindeki etkisi. Yayınlanmamış Doktora Tezi, Anadolu Üniversitesi Sosyal Bilimler Enstitüsü, Eskişehir.

Hoy, W. K., ve Tschannen-Moran, M. (2003). The conceptualisation and measurement of faculty trust in schools. Studies in Leading and Organising Schools, 191-207.

Hoy, W. K., ve Tschannen-Moran, M. (1999). Five faces of trust: An empirical confirmation in urban elementary schools. Journal of School Leadership, 9, 184-208.

Izgar, H., Ertekin, A.L., ve Deniz, M.E. (2009). Aynı iş kolunda çalışan sendikalı ve sendikasız işgörenlerin iş doyumu. Selçuk Üniversitesi Ahmet Keleşoğlu Ĕ̆itim Fakültesi Dergisi, 28, 105 -114.

İşcan, Ö. F. ve Sayın, U. (2010). Örgütsel adalet, iş tatmini ve örgütsel güven arasındaki ilişki. Atatürk Üniversitesi Iktisadi ve İdari Bilimler Dergisi, 24 (4), 2010.

Karadaş, H. (2013). Pozitif okul yönetiminin öğretmenlerinörgütsel bağlllı̆̆ına etki düzeyi. Yayımlanmamış Yüksek Lisans Tezi, Harran Üniversitesi Sosyal Bilimleri Enstitüsü, Şanliurfa.

Koç, Ç. E. (2008). Resmi ve özel ilköğretim okullarnnda görev yapan öğretmenlerin okul yöneticilerine gü̈enme düzeylerinin karşlaştırlması. Yayımlanmamış Yüksek Lisans Tezi, Gazi Üniversitesi Eğitim Bilimleri Enstitüsü, Ankara.

Koçel, T. (2014). Iş̧letme Yöneticiliği. İstanbul:Beta yayınları.

Kouzes, J. ve Posner, B. (1995). The leadership challenge. CA: Jossey Bass Inc. 
Leonard, P. E. (1999). Do teachers value collaboration? The impact of trust. Paper presented at the annual Meeting of the University Council for Educational Administration, Minneapolis, Minnesota.

Maddux, W. W., ve Brewer, M. B. (2005). Gender differences in the relational and collective bases for trust. Group Processes E Intergroup Relations, 8(2), 159-171.

Marks, H. M. (2000). Student engagement in instructional activity: Patterns in the elementary, middle, vehigh school years. American educational research journal, 37(1), 153-184.

Mitchell, R. M. ve Forsyth, P. B. (2004). Trust, the principal, and student identification. Paper presented at the Annual Meeting of The University Council for Education Administration. Kansas City, Missouri.

Molloy, P.L. (1998). A review of the managerial grid model of leadership and its role as a model of leadership culture. aquarius consulting.

Özdemir, S. (Editör). (2014). Türk eğitim sistemi ve okul yönetimi. (3. Baskı). Ankara: Pegem A Yayıncilik.

Özer, N., Demirtaş, H., Üstüner, M ve Cömert, M. (2006). Ortaöğretim öğretmenlerinin örgütsel güven algiları. Ege Eğitim Dergisi, 7(1), 103-124.

Öztürk, B. (2000). Sınıf içi etkileşim. Kuram ve Uygulamada Eğitim Yönetimi Dergisi, 6(4), 621-640.

Six, F. (2005). The trouble with trust: The dynamics of interpersonal trust building. Cheltenham, UK: Edward Elgar Publishing Limited.

Spector, M. D. ve Jones, G. E. (2004). Trust in the workplace: factors affecting trust formation between team members. The Journal of Social Psychology, 144(3), 311-321.

Şan, M. K. ve Şimşek, R. (2010). Sosyal Sermaye Kavramının Tarihsel-Sosyolojik Arka planı. Akademik Incelemeler Dergisi 6(1), 88-110.

Şan, M. K. (2007). Sosyal bilimlerde yıldızı yükselen yeni bir kavram: Sosyal sermaye ve Türkiye, Sosyoloji Yazılan I: Sakarya Üniversitesi Sosyoloji Bölümü ortak çalışması. Der: M. K. Şan, İstanbul: Kızılelma Yay. 282-323.

Şişman, M., S. Turan. (2004). Eğitim ve okul yönetimi. Eğitim kurumlar yönetici adaylarn seçme sinavnna hazırlık ve yetiştirme el kitabı. Ankara: Pegem A Yayıncılık.

Taş, A. (2007). Türk yönetim tarzl: Örgütlenme, sahiplik, insan kaynaklan ve Stratejik yönetim boyutlarnyla. Yayımlanmamış Doktora Tezi, Sakarya Üniversitesi, Sosyal Bilimler Enstitüsü, Sakarya.

Tanriöğen, A. (Edt.) (2011). Bilimsel araştırma yöntemleri. (2. Baskı). Ankara: Anı Yayıncılik.

Taymaz, H. (2003). İköğretim ve ortaöğretim okul müdürleri için okul yönetimi. (7. Baskı). Ankara: Pegem A Yayıncilik. 
Terekli, G. (2010). Örgütsel güven boyutlarn ve iş tatmini ilişkisi: Tekstil işletmesinde bir araştırma. Yayınlanmamış Yüksek Lisans Tezi, Anadolu Üniversitesi Sosyal Bilimler Enstitüsü, Eskişehir.

Tozlu, N. (2003a). Insandan devlete eğitim. Ankara: Yeni Türkiye Yayınları.

Tozlu, N. (2003b). Eğitim felsefesi. (2.Baskı). Ankara: Milli Eğitim Bakanlığı Yayınlanı.

Tschannen-Moran, M. ve Hoy, W. K. (1998). Trust in schools: A conceptual and empirical analysis. Journal of Educational Administration, 36(4). 334-352.

Uzbilek, A. (2006). Örgütlerde oluşan sosyal ilişkilerin örgütsel güzvenin alt boyutlarnna etkileri: Başkent üniversitesi örneği. Yayınlanmamış Yüksek Lisans Tezi, Başkent Üniversitesi Sosyal Bilimler Enstitüsü, Ankara.

Üstüner, M. (2016). Okul müdürleri yönetim tarzı ölçeğinin geçerlik ve gü̈venirlik çalışması. Yayımlanmamış Araştırma Raporu, İnönü Üniversitesi: Malatya.

\section{Kaynakça Bilgisi / Citation Information}

Karadaş, H. ve Özer, N. (2021). Okul müdürlerinin yönetim tarzları ile müdür öğretmen ilişkilerinde güven. OPUS-Uluslararası Toplum Araştırmaları Dergisi, 17(34), 1095-1123. DOI: 10.26466/opus.767321 